\title{
Schiff bases of N-(2-aminoethyl)-3-aminopropyltrimethoxysilane and its silatranes: Synthesis and characterization
}

\author{
GURJASPREET SINGH ${ }^{\mathrm{a}, *}$, AMANDEEP SAROA $^{\mathrm{a}}$, SADHIKA KHULLAR $^{\mathrm{b}}$ and \\ SANJAY K MANDAL ${ }^{\mathrm{b}, *}$ \\ ${ }^{a}$ Department of Chemistry, Panjab University, Chandigarh 160014, India \\ ${ }^{b}$ Department of Chemical Sciences, Indian Institute of Science Education and Research, \\ Mohali, Sector 81, Manauli PO, S.A.S. Nagar, Mohali (Punjab) 140306, India \\ e-mail: gjpsingh@pu.ac.in
}

MS received 12 August 2014; revised 14 October 2014; accepted 18 October 2014

\begin{abstract}
This paper aims at the introduction of azomethine group by the condensation reaction of $\mathrm{N}$ (2-aminoethyl)-3-aminopropyltrimethoxysilane with different compounds containing carbonyl group such as 2'-hydroxyacetophenone, salicylaldehyde, pyrrole-2-carboxaldehyde, acetylacetone and ethyl acetoacetate. Further, transesterification reaction of these Schiff base modified silanes with triethanolamine as a tripodal ligand leads to the synthesis of corresponding silatranes 1-5 bearing Schiff base functionalized long chain in the axial position. All the synthesized compounds are characterized by spectroscopic methods, elemental analysis and mass spectrometry. The authentication of Schiff base modified silatranes is scrutinized by single X-ray crystal structure of silatrane $\mathbf{1}$. The thermal stability of the five silatranes is studied by thermo-gravimetric analysis (TGA).
\end{abstract}

Keywords. Schiff base modified silane; Schiff base modified silatranes; N-(2-aminoethyl)-3-aminopropyltrimethoxysilane.

\section{Introduction}

Aminoalkyltrialkoxy functional silanes are of great importance due to a broad range of biological applications, ability to form hydrogen bonds and complex metallic species including potential originator materials for the synthesis of numerous $\mathrm{N}$-derivative silatranes. ${ }^{1-4}$ A variety of derivatives of aminoalkylsilatranes have been synthesized due to the reactivity of amino group with various reagents such as alkyl halides, aryl halides, phosphoryl halides, acid halides and carbonyl compounds. ${ }^{5-7}$ These silatranes are immensely significant due to intramolecular transannular dative $\mathrm{N} \rightarrow \mathrm{Si}$ bond which is influenced by the position, axial and equatorial, occupied by the substituents on the silicon as well as by cage effects. ${ }^{8,9}$

One of the important reactions of amino group is the condensation reaction with carbonyl group for the synthesis of compounds possessing azomethine moiety which are commonly known as Schiff bases. In recent years, Schiff base complexes with silicon have been studied broadly with the aim of shedding light on various aspects such as catalytic, anti-viral, anti-cancer, antibacterial and anti-fungal activities. ${ }^{10-13}$ These complexes

*For correspondence are valuable for theoretical as well as experimental chemists, as the steric and electronic factors of the silatranes can be adjusted systematically by introducing suitable substituents to bring about subtle structural variations. ${ }^{14-16}$ Prompted by these recent studies, we have worked on the modification at axial position of silatranes with various derivatives. ${ }^{17-19}$ In the present work, silatranes 1-5 containing azomethine functional group have been prepared by the reaction between corresponding Schiff base modified silanes of $\mathrm{N}$ (2-aminoethyl)-3-aminopropyltrimethoxysilane and triethanolamine. All the compounds have been characterized by various spectroscopic techniques and structure of silatrane $\mathbf{1}$ has been validated by X-ray diffraction analysis.

\section{Experimental}

\subsection{Chemicals and solvents}

N-(2-Aminoethyl)-3-aminopropyltrimethoxysilane (Aldrich), 2'-hydroxyacetophenone (Aldrich), salicylaldehyde (CDH), pyrrole-2-carboxaldehyde (Aldrich), acetylacetone (CDH), ethyl acetoacetate $(\mathrm{CDH})$ and triethanolamine (Aldrich) were used as supplied. All the syntheses were carried out under a dry nitrogen atmosphere using vacuum 
glass line. The organic solvents were dried and freshly distilled under an inert atmosphere according to standard procedures and stored under nitrogen.

\subsection{Physical measurements}

Infrared spectra were obtained as Nujol mulls and $\mathrm{KBr}$ pellet on a Perkin-Elmer RX-I FTIR spectrometer. CHN analyses were obtained on a Perkin-Elmer Model 2400 CHNS elemental analyser. Mass spectral measurements (ESI source with capillary voltage, $2500 \mathrm{~V}$ ) were carried out on a VG Analytical (70-S) spectrometer. ${ }^{1} \mathrm{H}$ and ${ }^{13} \mathrm{C}$ NMR spectra were recorded on a JEOL FT NMR (AL $300 \mathrm{MHz}$ ) spectrometer using $\mathrm{CDCl}_{3}$ as the solvent. Chemical shifts were reported in ppm relative to tetramethylsilane. The silicon element percentage was estimated gravimetrically in the form of silica. Thermal analysis was run on SDT Q 600V20.9 Build 20TGA Instrument. Sample was loaded in alumina pans and ramped at $10^{\circ} \mathrm{C} / \mathrm{min}$ to $800^{\circ} \mathrm{C}$ in dry air at $60 \mathrm{~mL} / \mathrm{min}$.

\section{$2.3 X$ X-ray crystallography}

Single crystals of silatrane $\mathbf{1}$ were transferred to mineral oil for manipulation, selection and mounting to a thin glass fibre on a goniometer head under intert atmosphere at $296 \mathrm{~K}\left(23^{\circ} \mathrm{C}\right)$. Initial crystal evaluation and data collection were performed on a Kappa APEX II diffractometer equipped with a CCD detector (with the crystal-to-detector distance fixed at $60 \mathrm{~mm}$ ) and sealed-tube monochromated Mo K $\alpha$ radiation. By using the program SAINT for the integration of the data, reflection profiles were fitted and values of F2 and $\sigma$ (F2) for each reflection were obtained. The data were processed with APEX2 program, ${ }^{20} \mathrm{XPREP}^{20}$ and corrected for absorption using SADABS. ${ }^{20}$ The crystal structure was solved and refined using SHELX $97 .{ }^{21}$

\subsection{General method for synthesis of silatranes 1-5}

In a round-bottomed two-necked flask, tripodal ligand triethanolamine $(2.35 \mathrm{mmol})$ was added in dry benzene $(30 \mathrm{~mL})$ and stirred at $25^{\circ} \mathrm{C}$ for $10 \mathrm{~min}$ in the presence of sodium ethoxide as catalyst. The Schiff base modified silane $(2.35 \mathrm{mmol})$ was then added dropwise to the stirring solution and the mixture was refluxed for $4 \mathrm{~h}$ in order to remove the methanol azeotropically formed during the reaction. The solvent was removed under reduced pressure and the silatrane was extracted with dry hexane upon stirring for $1 \mathrm{~h}$. 2.4a 2-(1-(2-(3-(2,8,9-trioxa-5-aza-1-sila-bicyclo[3.3. 3]undecan-1-yl)propylamino)ethylimino) ethyl)phenol 1: The silane 2-(1-(2-(3-trimethoxysilyl)propylamino) ethylimino)ethylphenol was used for the synthesis of yellow colour compound 1. Yield: $(0.75 \mathrm{~g}, 82 \%)$. M.p.: 159-161 ${ }^{\circ} \mathrm{C}$. Anal. Calcd for $\mathrm{C}_{19} \mathrm{H}_{31} \mathrm{~N}_{3} \mathrm{O}_{4} \mathrm{Si}$ : C, 58.01; H, 7.88; N, 10.68; Si, 7.12. Found: C, 57.60; H, 7.76; N, 10.55; $\mathrm{Si}, 6.93$. IR $\left(\mathrm{cm}^{-1}\right): v(\mathrm{~N} \rightarrow \mathrm{Si}) 582 \mathrm{~m}, v_{\mathrm{s}}(\mathrm{Si}-\mathrm{O})$ $750 \mathrm{~s}, v(\mathrm{C}-\mathrm{N}) 853 \mathrm{w}, v(\mathrm{C}-\mathrm{C}) 908 \mathrm{~m}, v_{\mathrm{as}}(\mathrm{Si}-\mathrm{O}) 1087$ vs, $v(\mathrm{C}-\mathrm{O}) 1117 \mathrm{vs}, v(\mathrm{C}=\mathrm{N}) 1611 \mathrm{vs}, v_{\mathrm{s}}\left(\mathrm{CH}_{2}\right) 2870$, $2916 \mathrm{~s}, v(\mathrm{OH}) 3326 \mathrm{~b} .{ }^{1} \mathrm{H}$ NMR $\left(\mathrm{CDCl}_{3}, \mathrm{ppm}\right): 0.29(\mathrm{t}$, $\left.2 \mathrm{H}, J=8.4 \mathrm{~Hz}, \mathrm{SiCH}_{2}\right), 1.49\left(\mathrm{~m}, 2 \mathrm{H}, \mathrm{CCH}_{2} \mathrm{C}\right), 2.29$ $\left(\mathrm{s}, 3 \mathrm{H}, \mathrm{CH}_{3}\right), 2.54$ (t, $\left.6 \mathrm{H}, J=5.7 \mathrm{~Hz}, \mathrm{NCH}_{2} \mathrm{C}\right), 2.65$ (m, $\left.2 \mathrm{H}, \mathrm{CH}_{2} \mathrm{NH}\right), 2.92\left(\mathrm{~m}, 2 \mathrm{H}, \mathrm{CH}_{2} \mathrm{NH}\right), 3.61(\mathrm{t}, 2 \mathrm{H}$, $\left.J=6.3 \mathrm{~Hz}, \mathrm{CH}_{2} \mathrm{~N}\right), 3.65\left(\mathrm{t}, 6 \mathrm{H}, J=5.7 \mathrm{~Hz}, \mathrm{OCH}_{2}\right)$, 6.61-7.40 (m, 4H, Ar-H), $17.31(\mathrm{OH}) .{ }^{13} \mathrm{C}$ NMR $\left(\mathrm{CDCl}_{3}, \mathrm{ppm}\right): 12.99\left(\mathrm{SiCH}_{2}\right), 14.42\left(\mathrm{CH}_{3}\right), 25.09$ $\left(\mathrm{CCH}_{2} \mathrm{C}\right), 49.77\left(\mathrm{CH}_{2} \mathrm{NH}\right), 50.05\left(\mathrm{CH}_{2} \mathrm{NH}\right), 51.29$ $\left(\mathrm{CH}_{2} \mathrm{~N}\right), 53.14\left(\mathrm{CH}_{2} \mathrm{~N}\right), 57.83\left(\mathrm{OCH}_{2}\right), 116-132.14$ $($ Ar-C), $163.84(\mathrm{C}=\mathrm{N})$. MS: $m / z$ (relative abundance (\%), assignment): 174.2 [36.8, $\mathrm{Si}\left(\mathrm{OCH}_{2} \mathrm{CH}_{2}\right)_{3} \mathrm{~N}^{+}$], $192.2\left[4.3, \quad \mathrm{Si}\left(\mathrm{OCH}_{2} \mathrm{CH}_{2}\right)_{3} \mathrm{~N}^{+} . \mathrm{NH}_{3}\right], \quad 394.2 \quad[100$, $\left.(\mathrm{M}+\mathrm{H})^{+}\right], 416.3\left[3.38,(\mathrm{M}+\mathrm{Na})^{+}\right]$.

2.4b 2-((2-(3-(2,8,9-trioxa-5-aza-1-sila-bicyclo[3.3. 3]undecan-1-yl)propylamino)ethylimino) methyl)phenol 2: The silane 2-(2-(3-trimethoxysilyl)propylamino) ethylimino)methylphenol was used for the synthesis of yellow colour compound 2. Yield: $(0.79 \mathrm{~g}, 85 \%)$. M.p.: $152-154^{\circ} \mathrm{C}$. Anal. Calcd for $\mathrm{C}_{18} \mathrm{H}_{29} \mathrm{~N}_{3} \mathrm{O}_{4} \mathrm{Si}$ : C, 56.99; H, 7.65; N, 11.08; Si, 7.38. Found: C, 56.75; H, 7.38; N, 10.62; $\mathrm{Si}, 7.13$. IR $\left(\mathrm{cm}^{-1}\right): v(\mathrm{~N} \rightarrow \mathrm{Si}) 583 \mathrm{~m}$, $v_{\mathrm{s}}(\mathrm{Si}-\mathrm{O}) 748 \mathrm{~s}, v(\mathrm{C}-\mathrm{N}) 854 \mathrm{w}, v(\mathrm{C}-\mathrm{C}) 908 \mathrm{~m}, v_{\mathrm{as}}(\mathrm{Si}-$ O) 1086 vs, v $(\mathrm{C}-\mathrm{O}) 1123$ vs, v $(\mathrm{C}=\mathrm{N}) 1626$ vs, v $\left(\mathrm{CH}_{2}\right)$ 2872, $2922 \mathrm{~s}, v(\mathrm{OH}) 3303$ b. ${ }^{1} \mathrm{H} \mathrm{NMR}\left(\mathrm{CDCl}_{3}\right.$, ppm): 0.27 (t, $\left.2 \mathrm{H}, J=8.4 \mathrm{~Hz}, \mathrm{SiCH}_{2}\right), 1.48(\mathrm{~m}, 2 \mathrm{H}$, $\left.\mathrm{CCH}_{2} \mathrm{C}\right), 2.50\left(\mathrm{t}, 6 \mathrm{H}, J=5.7 \mathrm{~Hz}, \mathrm{NCH}_{2}\right), 2.66(\mathrm{~m}, 2 \mathrm{H}$, $\left.\mathrm{CH}_{2} \mathrm{NH}\right), 2.86\left(\mathrm{~m}, 2 \mathrm{H}, \mathrm{CH}_{2} \mathrm{NH}\right), 3.59$ (t, $2 \mathrm{H}, J=6.3$ $\mathrm{Hz}, \mathrm{CH}_{2} \mathrm{~N}$ ), 3.61 (t, $\left.6 \mathrm{H}, J=5.7 \mathrm{~Hz}, \mathrm{OCH}_{2}\right), 6.72-7.19$ $(\mathrm{m}, 4 \mathrm{H}, \mathrm{Ar}-\mathrm{H}), 8.39(\mathrm{~s}, 1 \mathrm{H}, \mathrm{CH}=\mathrm{N}), 13.22(\mathrm{OH}) .{ }^{13} \mathrm{C}$ NMR $\left(\mathrm{CDCl}_{3}, \mathrm{ppm}\right): 13.03\left(\mathrm{SiCH}_{2}\right), 24.88\left(\mathrm{CCH}_{2} \mathrm{C}\right)$, $51.43\left(\mathrm{CH}_{2} \mathrm{NH}\right), 53.34\left(\mathrm{CH}_{2} \mathrm{~N}\right), 57.03\left(\mathrm{CH}_{2} \mathrm{~N}\right), 57.41$ $\left(\mathrm{NCH}_{2}\right), 59.16\left(\mathrm{OCH}_{2}\right), 117-131.67$ (Ar-C), 160.84 $(\mathrm{C}=\mathrm{N})$. MS: $m / z$ (relative abundance $(\%)$, assignment): $174.1\left[28.7, \mathrm{Si}\left(\mathrm{OCH}_{2} \mathrm{CH}_{2}\right)_{3} \mathrm{~N}^{+}\right], 192.2$ [3.1, $\mathrm{Si}\left(\mathrm{OCH}_{2} \mathrm{CH}_{2}\right)_{3} \mathrm{~N}^{+} . \mathrm{NH}_{3}$ ], 380.3 [100, $\left.(\mathrm{M}+\mathrm{H})^{+}\right], 402.3$ $\left[5.2,(\mathrm{M}+\mathrm{Na})^{+}\right]$.

2.4c $\quad N^{1}-\left((1 H\right.$-pyrrol-2-yl)methylene $)-N^{2}-(3-(2,8,9-$ trioxa-5-aza-1-sila-bicyclo[3.3.3]undecan-1-yl)ethane1,2-diamine 3: The silane $\mathrm{N}^{1}-(1 \mathrm{H}-$ pyrrol-2-yl)methlene)- $\mathrm{N}^{2}$-(3-trimethoxysilyl)propyl)ethane-1,2-diamine 
was used for the synthesis of yellow colour compound 3. Yield: $(0.76 \mathrm{~g}, 80 \%)$. M.p.: $170-172^{\circ} \mathrm{C}$. Anal. Calcd for $\mathrm{C}_{16} \mathrm{H}_{28} \mathrm{~N}_{4} \mathrm{O}_{3} \mathrm{Si}$ : C, 54.54; $\mathrm{H}, 7.95 ; \mathrm{N}, 15.90 ; \mathrm{Si}$, 7.95. Found: C, 54.13; H, 7.89; N, 15.32; Si, 7.47. IR $\left(\mathrm{cm}^{-1}\right): v(\mathrm{~N} \rightarrow \mathrm{Si}) 582 \mathrm{~m}, v_{\mathrm{s}}(\mathrm{Si}-\mathrm{O}) 753 \mathrm{~s}, v(\mathrm{C}-\mathrm{N})$ $809 \mathrm{w}, v(\mathrm{C}-\mathrm{C}) 910 \mathrm{~m}, v_{\mathrm{as}}(\mathrm{Si}-\mathrm{O}) 1096 \mathrm{vs}, v(\mathrm{C}-\mathrm{O})$ 1126 vs, $v(\mathrm{C}=\mathrm{N}) 1636$ vs, v $\left(\mathrm{CH}_{2}\right) 2827,2925 \mathrm{~s}$, v (NH) 3043 b. ${ }^{1} \mathrm{H} \mathrm{NMR}\left(\mathrm{CDCl}_{3}, \mathrm{ppm}\right): 0.50(\mathrm{t}, 2 \mathrm{H}$, $\left.J=8.4 \mathrm{~Hz}, \mathrm{SiCH}_{2}\right), 1.74\left(\mathrm{~m}, 2 \mathrm{H}, \mathrm{CCH}_{2} \mathrm{C}\right), 2.99$ (t, $\left.6 \mathrm{H}, J=5.7 \mathrm{~Hz}, \mathrm{NCH}_{2}\right), 3.02\left(\mathrm{~m}, 2 \mathrm{H}, \mathrm{CH}_{2} \mathrm{NH}\right)$, $3.72\left(\mathrm{~m}, 2 \mathrm{H}, \mathrm{CH}_{2} \mathrm{NH}\right), 3.90(\mathrm{t}, 2 \mathrm{H}, J=6.3 \mathrm{~Hz}$, $\left.\mathrm{CH}_{2} \mathrm{~N}\right), 3.94\left(\mathrm{t}, 6 \mathrm{H}, J=5.7 \mathrm{~Hz}, \mathrm{OCH}_{2}\right), 6.34-7.04$ (m, 4H, Pyrrole-H), $8.28(\mathrm{~s}, 1 \mathrm{H}, \mathrm{CH}=\mathrm{N}) \cdot{ }^{13} \mathrm{C}$ NMR $\left(\mathrm{CDCl}_{3}, \mathrm{ppm}\right): 13.72\left(\mathrm{SiCH}_{2}\right), 24.73\left(\mathrm{CCH}_{2} \mathrm{C}\right), 50.05$ $\left(\mathrm{CH}_{2} \mathrm{NH}\right), 50.28\left(\mathrm{CH}_{2} \mathrm{NH}\right), 56.67 \quad\left(\mathrm{CH}_{2} \mathrm{~N}\right), 56.93$ $\left(\mathrm{NCH}_{2}\right), 58.64\left(\mathrm{OCH}_{2}\right), 108.40-127.83$ (Pyrrole-C), $151.97(\mathrm{C}=\mathrm{N})$. MS: $m / z$ (relative abundance $(\%)$, assignment): 174.1 [24.0, $\left.\mathrm{Si}\left(\mathrm{OCH}_{2} \mathrm{CH}_{2}\right)_{3} \mathrm{~N}^{+}\right], 192.2$ [4.8, $\left.\mathrm{Si}\left(\mathrm{OCH}_{2} \mathrm{CH}_{2}\right)_{3} \mathrm{~N}^{+} . \mathrm{NH}_{3}\right], 353.3\left[100,(\mathrm{M}+\mathrm{H})^{+}\right]$, $375.3\left[6.4,(\mathrm{M}+\mathrm{Na})^{+}\right]$.

2.4d 4-(2-(3-(2,8,9-trioxa-5-aza-1-sila-bicyclo[3.3.3] undecan-1-yl)propylamino)ethylaminopent-3-en-2-one 4: The silane 4-(2-(3-(trimethoxysilyl)propylamino) ethylamino)pent-3-en-2-one was used for the synthesis of white colour compound 4. Yield: $(0.71 \mathrm{~g}, 77 \%)$. M.p.: $179-181^{\circ} \mathrm{C}$. Anal. Calcd for $\mathrm{C}_{16} \mathrm{H}_{31} \mathrm{~N}_{3} \mathrm{O}_{4} \mathrm{Si}$ : C, 53.78; H, 8.68; N, 11.76; Si, 7.84. Found: C, 53.53; H, 8.07; N, 11.04; $\mathrm{Si}, 7.62 . \mathrm{IR}\left(\mathrm{cm}^{-1}\right): v(\mathrm{~N} \rightarrow \mathrm{Si}) 582 \mathrm{~m}, v_{\mathrm{s}}$ $(\mathrm{Si}-\mathrm{O}) 753 \mathrm{~s}, v(\mathrm{C}-\mathrm{N}) 805 \mathrm{w}, v(\mathrm{C}-\mathrm{C}) 878 \mathrm{~m}, v_{\text {as }}(\mathrm{Si}-\mathrm{O})$ 1084 vs, $v(\mathrm{C}-\mathrm{O}) 1179$ vs, $v(\mathrm{C}=\mathrm{C}) 1551$ vs, $v(\mathrm{C}=\mathrm{N})$ 1611 vs, v $\left(\mathrm{CH}_{2}\right) 2871,2927 \mathrm{~s}, v(\mathrm{~N}-\mathrm{H}) 3293$ b. ${ }^{1} \mathrm{H}$ NMR ( $\left.\mathrm{CDCl}_{3}, \mathrm{ppm}\right): 0.27\left(\mathrm{t}, 2 \mathrm{H}, J=8.4 \mathrm{~Hz}, \mathrm{SiCH}_{2}\right)$, $1.45\left(\mathrm{~m}, 2 \mathrm{H}, \mathrm{CCH}_{2} \mathrm{C}\right), 1.86\left(\mathrm{~s}, 3 \mathrm{H}, \mathrm{CCH}_{3}\right), 1.88(\mathrm{~s}, 3 \mathrm{H}$, $\mathrm{CCH}_{3}$ ), 2.47 (t, $\left.6 \mathrm{H}, J=5.7 \mathrm{~Hz}, \mathrm{NCH}_{2}\right), 2.67(\mathrm{~m}, 2 \mathrm{H}$, $\left.\mathrm{CH}_{2} \mathrm{NH}\right), 2.70\left(\mathrm{~m}, 2 \mathrm{H}, \mathrm{CH}_{2} \mathrm{NH}\right), 3.27$ (t, $2 \mathrm{H}, J=6.3$ $\left.\mathrm{Hz}, \mathrm{CH}_{2} \mathrm{~N}\right), 3.64\left(\mathrm{t}, 6 \mathrm{H}, J=5.7 \mathrm{~Hz}, \mathrm{OCH}_{2}\right), 4.80$ (s, $1 \mathrm{H}, \mathrm{C}=\mathrm{CH}), 10.59(\mathrm{~s}, 1 \mathrm{H}, \mathrm{NH}) \cdot{ }^{13} \mathrm{C} \mathrm{NMR}\left(\mathrm{CDCl}_{3}\right.$, ppm): $12.89\left(\mathrm{SiCH}_{2}\right), 18.97\left(\mathrm{CH}_{3}\right), 24.91\left(\mathrm{CCH}_{2} \mathrm{C}\right)$, $49.29\left(\mathrm{CH}_{2} \mathrm{NH}\right), 51.41\left(\mathrm{CH}_{2} \mathrm{NH}\right), 52.07\left(\mathrm{CH}_{2} \mathrm{NH}\right)$, $57.92\left(\mathrm{CH}_{2} \mathrm{~N}\right), 58.98\left(\mathrm{OCH}_{2}\right), 96.22(\mathrm{C}=\mathrm{CH}), 162.40$ $(\boldsymbol{C}=\mathrm{CH}), 194.24(\mathrm{C}=\mathrm{O})$. MS: $m / z$ (relative abundance (\%), assignment): $174.1 \quad\left[11.2 \mathrm{Si}\left(\mathrm{OCH}_{2} \mathrm{CH}_{2}\right)_{3} \mathrm{~N}^{+}\right]$, $192.2\left[2.9, \quad \mathrm{Si}\left(\mathrm{OCH}_{2} \mathrm{CH}_{2}\right)_{3} \mathrm{~N}^{+} . \mathrm{NH}_{3}\right], \quad 358.3 \quad[100$, $\left.(\mathrm{M}+\mathrm{H})^{+}\right], 380.3\left[16.75,(\mathrm{M}+\mathrm{Na})^{+}\right]$.

2.4e ethyl-3-(2-(3-(2,8,9-trioxa-5-aza-1-sila-bicyclo [3.3.3]undecan-1 yl)propylamino)ethyl-amino)but-2-enoate 5: The silane ethyl-3-(2-(3-(trimethoxysilyl) propylamino)ethylamino)but-2-enoate was used for the synthesis of white colour compound 4. Yield: $\left(0.73\right.$ g, 79\%). M.p.: $192-194^{\circ}$ C. Anal. Calcd for
$\mathrm{C}_{17} \mathrm{H}_{33} \mathrm{~N}_{3} \mathrm{O}_{5} \mathrm{Si}: \mathrm{C}, 52.71 ; \mathrm{H}, 8.52 ; \mathrm{N}, 10.85 ; \mathrm{Si}, 7.23$. Found: C, 52.60; H, 7.80; N, 10.39; Si, 7.09. IR $\left(\mathrm{cm}^{-1}\right)$ : $v(\mathrm{~N} \rightarrow \mathrm{Si}) 582 \mathrm{~m}, v_{\mathrm{s}}(\mathrm{Si}-\mathrm{O}) 775 \mathrm{~s}, v(\mathrm{C}-\mathrm{N}) 801 \mathrm{w}, v$ (C-C) $910 \mathrm{~m}, v_{\text {as }}(\mathrm{Si}-\mathrm{O}) 1053 \mathrm{vs}, v(\mathrm{C}-\mathrm{O}) 1163 \mathrm{vs}$, $v(\mathrm{C}=\mathrm{C}) 1586$ vs, $v(\mathrm{C}=\mathrm{N}) 1643$ vs, $v_{\mathrm{s}}\left(\mathrm{CH}_{2}\right) 2815$, $2925 \mathrm{~s}, v(\mathrm{~N}-\mathrm{H}) 3289$ b. ${ }^{1} \mathrm{H}$ NMR $\left(\mathrm{CDCl}_{3}, \mathrm{ppm}\right): 0.27$ $\left(\mathrm{t}, 2 \mathrm{H}, J=8.4 \mathrm{~Hz}, \mathrm{SiCH}_{2}\right), 1.16(\mathrm{t}, 3 \mathrm{H}, J=7.2$ $\left.\mathrm{Hz}, \mathrm{CH}_{3}\right), 1.46\left(\mathrm{~m}, 2 \mathrm{H}, \mathrm{CCH}_{2} \mathrm{C}\right), 1.85$ (s, 3H, $\mathrm{CCH}_{3}$ ), $2.51\left(\mathrm{~m}, 2 \mathrm{H}, \mathrm{CH}_{2} \mathrm{NH}\right), 2.67\left(\mathrm{~m}, 2 \mathrm{H}, \mathrm{CH}_{2} \mathrm{NH}\right), 2.69$ $\left(\mathrm{t}, 6 \mathrm{H}, J=5.7 \mathrm{~Hz}, \mathrm{NCH}_{2}\right), 3.21(\mathrm{t}, 2 \mathrm{H}, J=6.3$ $\left.\mathrm{Hz}, \mathrm{CH}_{2} \mathrm{~N}\right), 3.64\left(\mathrm{t}, 6 \mathrm{H}, J=5.7 \mathrm{~Hz}, \mathrm{OCH}_{2}\right), 3.98$ $\left(\mathrm{q}, 2 \mathrm{H}, J=7.2 \mathrm{~Hz}, \mathrm{CH}_{2} \mathrm{O}\right), 4.29(\mathrm{~s}, 1 \mathrm{H}, \mathrm{C}=\mathrm{CH})$, $8.48(\mathrm{~s}, 1 \mathrm{H}, \mathrm{NH}) .{ }^{13} \mathrm{C} \mathrm{NMR}\left(\mathrm{CDCl}_{3}, \mathrm{ppm}\right): 12.96$ $\left(\mathrm{SiCH}_{2}\right), 14.80\left(\mathrm{CH}_{3}\right), 19.55\left(\mathrm{CH}_{3}\right), 24.99\left(\mathrm{CCH}_{2} \mathrm{C}\right)$, $28.70\left(\mathrm{COCH}_{3}\right), 49.65\left(\mathrm{CH}_{2} \mathrm{NH}\right), 51.39\left(\mathrm{CH}_{2} \mathrm{NH}\right)$, $52.91\left(\mathrm{CH}_{2} \mathrm{~N}\right), 57.91\left(\mathrm{CH}_{2} \mathrm{~N}\right), 57.97\left(\mathrm{OCH}_{2}\right), 59.40$ $\left(\mathrm{OCH}_{2}\right), 96.21 \quad(\mathrm{C}=\boldsymbol{C H}), 161.22(\boldsymbol{C}=\mathrm{CH}), 170.20$ $(\mathrm{C}=\mathrm{O}$ ). MS: $m / z$ (relative abundance $(\%)$, assignment): 174.1 [8.9, $\left.\mathrm{Si}\left(\mathrm{OCH}_{2} \mathrm{CH}_{2}\right)_{3} \mathrm{~N}^{+}\right], 192.2 \quad[2.9$, $\left.\mathrm{Si}\left(\mathrm{OCH}_{2} \mathrm{CH}_{2}\right)_{3} \mathrm{~N}^{+} . \mathrm{NH}_{3}\right], 388.3\left[100,(\mathrm{M}+\mathrm{H})^{+}\right], 411.3$ $\left[3.2,(\mathrm{M}+\mathrm{Na})^{+}\right]$.

\section{Results and Discussion}

\subsection{Synthesis}

The reported route for the synthesis of Schiff base modified silatranes is direct condensation reaction between silatranes and different compounds containing carbonyl group. It is attributed to more stability of silatranes towards hydrolysis and purity than alkoxysilane analogues. But in this paper, we have tried the other way round for the synthesis of Schiff base modified silanes from N-(2-aminoethyl)-3aminopropyltrimethoxysilane in good yield and pure form. Further, silatranes 1-5 were synthesized by the reaction of Schiff base modified silanes with triethanolamine in the presence of sodium ethoxide as catalyst as shown in scheme 1 . The results we have obtained by our route are comparable in terms of purity and hydrolytic stability with earlier methods. Both condensation and transesterification reactions were carried out at $80^{\circ} \mathrm{C}$ in benzene as solvent using Dean-Stark apparatus to remove water and alcohol respectively.

\subsection{Spectroscopic studies}

3.2a FTIR spectroscopy: The IR spectra of all silatranes 1-5 exhibit characteristic absorption bands of silatranyl group and assigned on the basis of literature. ${ }^{22}$ In IR spectra, the decisive absorption bands are $\mathrm{N} \rightarrow \mathrm{Si}$, $\mathrm{Si}-\mathrm{O}$ and $\mathrm{C}=\mathrm{N}$ which are found to be in accordance 


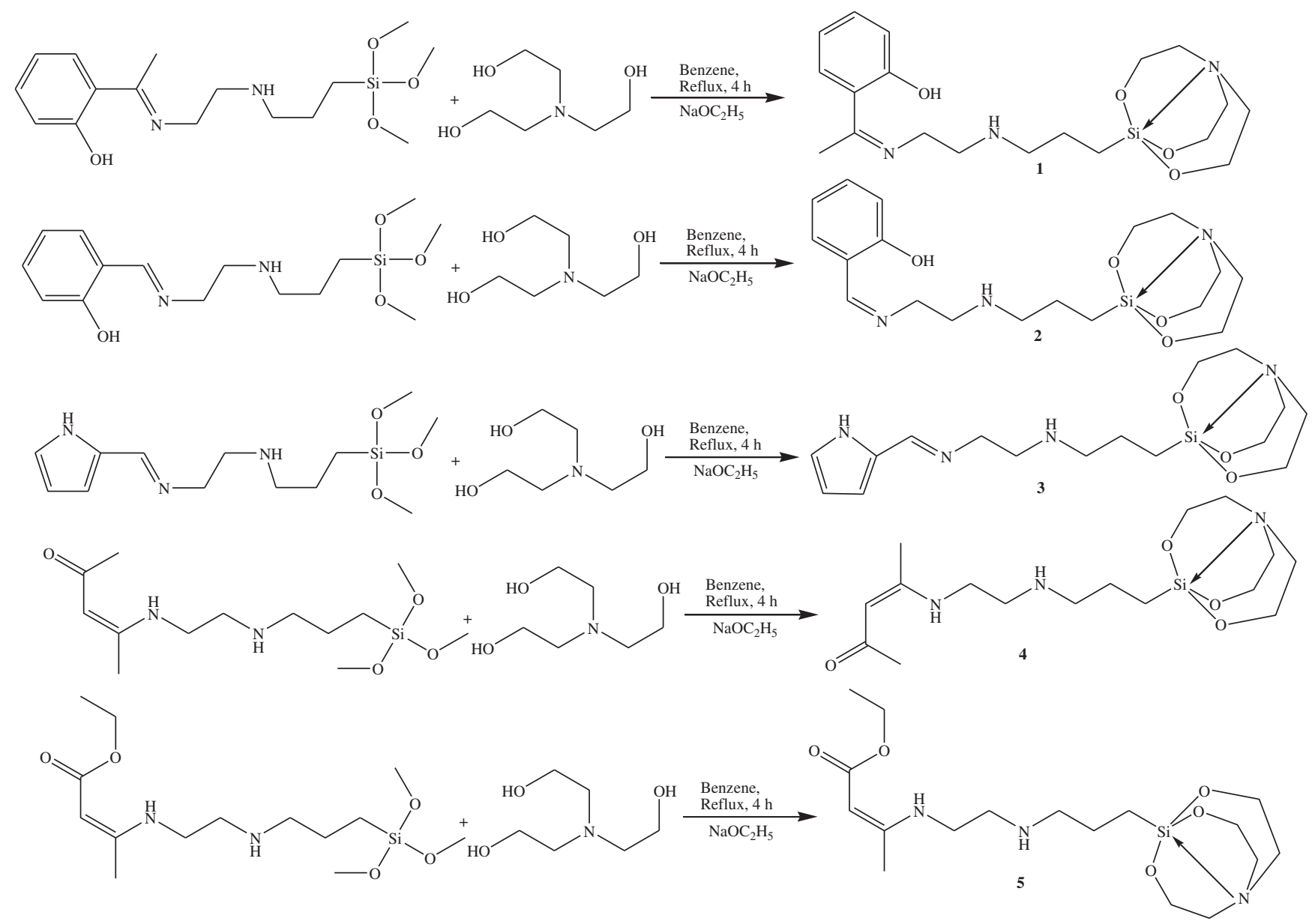

Scheme 1. Synthesis of Schiff base modified silatranes.

with desired synthesized compounds. The absorption band for $\mathrm{N} \rightarrow \mathrm{Si}$ stretching band is observed in the region of $585-582 \mathrm{~cm}^{-1}$ which is the distinctive feature of silatranes $\mathbf{1 - 5}$. The $\mathrm{Si}-\mathrm{O}$ absorption band is assigned in the region of $1096-1084 \mathrm{~cm}^{-1}$ for $\mathbf{1 - 5}$ which is due to the formation of atrane ring by transesterification reaction. The characteristic $\mathrm{C}=\mathrm{N}$ stretching band is assigned in the region of $1650-1610 \mathrm{~cm}^{-1}$ for silatranes $\mathbf{1 - 3}$. In the case of silatranes $\mathbf{4}$ and $\mathbf{5}$, the region of $1640-1610 \mathrm{~cm}^{-1}$ corresponds to $\mathrm{C}=\mathrm{O}$ stretching mode and absorption band for $\mathrm{C}=\mathrm{C}$ are also observed in $1600-1570 \mathrm{~cm}^{-1}$ range. For the compounds 1 and 2, OH stretching band is appeared at 3400$3200 \mathrm{~cm}^{-1}$ whereas NH stretching band is assigned to 3293-3289 $\mathrm{cm}^{-1}$ for compounds $\mathbf{4}$ and $\mathbf{5}$.

3.2b Multinuclear NMR: Multinuclear $\left({ }^{1} \mathrm{H}\right.$ and $\left.{ }^{13} \mathrm{C}\right)$ NMR spectra of all compounds support the structure of Schiff base modified silanes and silatranes. The methoxy group of silanes is replaced by atranyl moiety $\left(\mathrm{OCH}_{2} \mathrm{CH}_{2}\right)_{3} \mathrm{~N}$ which consists of two intense triplets due to $\mathrm{NCH}_{2}$ (2.65-2.69 ppm) and $\mathrm{OCH}_{2}$ protons (3.63-3.65 ppm) for Schiff base modified silatranes 1-5. In ${ }^{1} \mathrm{H}$ NMR spectra, an upfield triplet appears for the methylene group attached to the silicon atom i.e., $\mathrm{SiCH}_{2}$ of all silatranes, that clearly points out the increase in the electron density on the silicon due to the presence of silatranyl skeleton. The most speculative azomethine group $\mathrm{C}=\mathrm{N}$, the linker moiety in Schiff base modified compounds confirms the synthesis of desired compounds. The methylene protons attached to azomethine group are validated by triplet in the wide range which depends upon exocyclic group attached. In ${ }^{1} \mathrm{H}$ NMR spectra, downfield singlet is observed for $\mathrm{CH}=\mathrm{N}$ protons for compounds $\mathbf{1 - 3}$ at $7.95-8.35 \mathrm{ppm}$ for the silanes. The proton signals are observed for $\mathrm{CH}=\mathrm{C}(4.29-4.83 \mathrm{ppm})$ which are indicative of $\pi$-electron density delocalization for the compounds $\mathbf{4}$ and $\mathbf{5}$. In ${ }^{1} \mathrm{H}$ NMR, broad singlet is observed at $10.72 \mathrm{ppm}$ due to $\mathrm{NH}$ moiety which is indicative of the keto-enamine form for compound 4. In compound $\mathbf{5}$, proton of $\mathrm{NH}$ is appeared upfield than $\mathrm{NH}$ proton of compound $\mathbf{4}$ because inductive effect of ethoxy group leads to less intramolecular O....H-N hydrogen bonding in compound $\mathbf{5}$. 


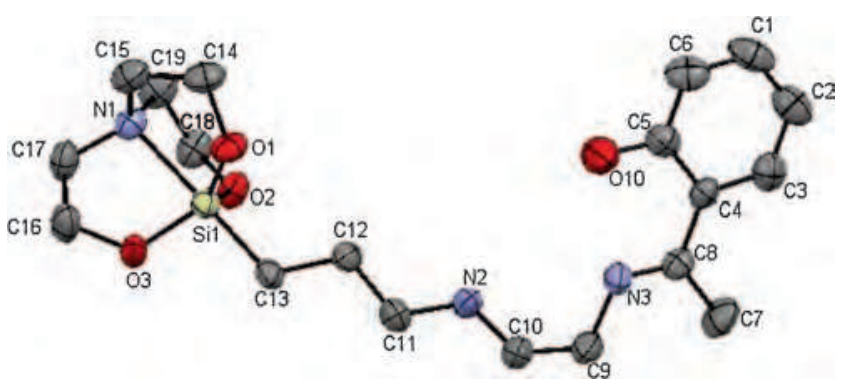

Figure 1. ORTEP diagram of compound 1.

In ${ }^{13} \mathrm{C}$ NMR spectra, the methylene carbon of propyl chain attached to silicon atom appears as the most shielded carbon atom which is observed around 12.89$\mathbf{1 3 . 0 3} \mathrm{ppm}$ for all silatranes $\mathbf{1 - 5}$. The peak for $\mathrm{CCH}_{2} \mathrm{~N}$ attached to azomethine group are shown as peak in the region of 52.00-56.50 ppm depending upon the exocyclic moiety. The carbons of azomethine group $\mathrm{CH}=\mathrm{N}$ are observed at $163.84,160.84$ and $151.97 \mathrm{ppm}$ for the silatranes 1, 2 and 3 respectively. In ${ }^{13} \mathrm{C}$ NMR, the signal for enamine carbon $(\mathrm{NC}=\mathrm{CH})$ assigned at 162.40 and $\mathbf{1 6 1 . 2 2} \mathrm{ppm}$ for $\mathbf{4}$ and $\mathbf{5}$ respectively.

3.2c Mass spectrometry: Mass spectra of silatranes 1-5 show their respective molecular ion peaks along with the characteristic features of silatrane. The mass spectra constitute peaks $(\mathrm{M}+\mathrm{H})^{+}$at $\mathrm{m} / \mathrm{z} 394,380$, 353,358 and 388 along with other peaks $(\mathrm{M}+\mathrm{Na})^{+}$at $\mathrm{m} / \mathrm{z}$ 417, 402, 375, 380 and 410 for compounds 1-5 respectively. The peaks observed at $\mathrm{m} / \mathrm{z} 274,273$ and 274 show cleavage of azomethine bond in the compounds 1-3 respectively. The compounds $\mathbf{4}$ and $\mathbf{5}$ have shown the cleavage of olefinic bond at m/z 301 and 300 respectively (supplementary data scheme 2. General fragmentation pattern of N-propylsilatranylamine).

\subsection{X-ray crystallography}

The suitable single crystal for compound $\mathbf{1}$ has grown in chloroform-hexane mixture. Compound $\mathbf{1}$ crystallizes in the triclinic $P-1$ space group as depicted in figure 1 . Selected crystallographic data and structure refinement parameters are given in table 1 . Selected bond lengths and bond angles are listed in table 2. The silicon atom in 1 exhibits a distorted trigonal-bipyramidal coordination polyhedron with the aminopropyl moiety spanning one axial (N1) and three equatorial sites (O1, O2, O3) whereas the other trans-apical position is occupied by the azomethine functional aromatic ring. The trianionic $\mathrm{N}\left(\mathrm{CH}_{2} \mathrm{CH}_{2} \mathrm{O}-\right)$ entities act as tetradendate ligands coordinating each to silicon to form five membered rings, so that the transannular $\mathrm{Si}-\mathrm{N}$ bond formed. The $\mathrm{O}$ atoms of the tetradendate ligand occupy equatorial positions and the $\mathrm{N}$ donor is present at apical site trans to azomethinefunctionalized alkyl chain. The most important parameter i.e., $\mathrm{N} \rightarrow \mathrm{Si}$ bond length is 2.157(4) $\AA$. The $\mathrm{Si}-\mathrm{N}$ bond distances are noticeably shorter than the sum of the van der Waals radii and indicate weak bonding interactions between both atoms. Any effect of azomethine group is not observed on the $\mathrm{Si}-\mathrm{N}$ bond distance due to presence of intervening propyl chain. With regard to the geometrical features of the C-Si-N fragment, the structure has revealed near linearity of $\mathrm{C}(13,32,51)$ $\mathrm{Si}(1,2,3)-\mathrm{N}(1,4,7)$ [178.6 $\mathrm{A}$. There are three independent silatranes molecules in the asymmetric unit. These

Table 1. X-ray crystal data and structure refinement parameters for compound $\mathbf{1 .}$

\begin{tabular}{lc}
\hline Empirical formula & $\mathrm{C}_{19} \mathrm{H}_{31.33} \mathrm{~N}_{3} \mathrm{O}_{4.17} \mathrm{Si}$ \\
Formula weight & 396.56 \\
$\mathrm{~T}(\mathrm{~K})$ & $270(2)$ \\
$\lambda(\AA)$ & 0.71073 \\
Crystal system, space group & Triclinc, $P-1$
\end{tabular}

Unit cell dimensions

$\mathrm{a}(\AA)$
$\mathrm{b}(\AA)$
$\mathrm{c}(\AA)$
$\alpha\left(^{\circ}\right)$
$\beta\left(^{\circ}\right)$
$\gamma\left({ }^{\circ}\right)$
$\mathrm{V}\left(\AA^{3}\right)$
$\mathrm{Z}$

a $(\AA)$

b $(\AA)$

$\alpha\left(^{\circ}\right)$

$\beta\left(^{\circ}\right)$

$\mathrm{V}\left(\AA^{3}\right)$

$\mathrm{Z}$ 
Table 2. Selected bond lengths $(\AA)$ and angles $\left(^{\circ}\right)$ of $\mathbf{1}$.

\begin{tabular}{lccccc}
\hline \multicolumn{2}{c}{ Molecule I } & \multicolumn{2}{c}{ Molecule II } & \multicolumn{2}{c}{ Molecule III } \\
\hline Si1-O1 & $1.661(4)$ & Si2-O4 & $1.667(4)$ & Si3-O7 & $1.659(4)$ \\
Si1-O2 & $1.666(4)$ & Si2-O5 & $1.652(3)$ & Si3-O8 & $1.644(4)$ \\
Si1-O3 & $1.656(3)$ & Si2-O6 & $1.660(4)$ & Si3-O9 & $1.663(4)$ \\
Si1-N1 & $2.157(4)$ & Si2-N4 & $2.157(4)$ & Si3-N7 & $2.173(4)$ \\
Si1-C13 & $1.872(5)$ & Si2-C32 & $1.868(5)$ & Si3-C51 & $1.882(5)$ \\
O3-Si1-O2 & $118.5(2)$ & O5-Si2-O6 & $118.2(2)$ & O8-Si3-O7 & $119.06(19)$ \\
O2-Si1-O1 & $119.2(2)$ & O6-Si2-O4 & $119.2(2)$ & O7-Si3-O9 & $118.3(2)$ \\
O2-Si1-C13 & $96.7(2)$ & O6-Si2-C32 & $97.3(2)$ & O8-Si3-O9 & $118.0(2)$ \\
O3-Si1-N1 & $82.94(17)$ & O5-Si2-N4 & $83.20(2)$ & O8-Si3-C51 & $98.1(2)$ \\
O3-Si1-O1 & $118.21(19)$ & O4-Si2-N4 & $82.24(18)$ & O8-Si3-N7 & $82.98(19)$ \\
O3-Si1-C13 & $96.2(2)$ & O5-Si2-O4 & $117.77(19)$ & O9-Si3-N7 & $82.73(18)$ \\
O1-Si1-N1 & $83.65(19)$ & O5-Si2-C32 & $98.2(2)$ & O7-Si3-N7 & $82.74(19)$ \\
O1-Si1-C13 & $96.7(2)$ & O4-Si2-C32 & $96.6(2)$ & O9-Si3-C51 & $97.7(2)$ \\
O2-Si1-N1 & $83.06(19)$ & O6-Si2-N4 & $82.57(18)$ & O7-Si3-C51 & $95.7(2)$ \\
C13-Si1-N1 & $179.1(2)$ & C32-Si2-N4 & $178.5(2)$ & C51-Si3-N7 & $178.4(3)$ \\
\hline
\end{tabular}

independent molecules differ in the orientation of alkyl chain. This is evident from the value of torsional angles. The torsional angle around Si1-C13-C12-C11 is $179.42^{\circ}$, $\mathrm{Si} 2-\mathrm{C} 32-\mathrm{C} 31-\mathrm{C} 30$ is $169.56^{\circ}$ and $\mathrm{Si} 3-\mathrm{C} 51-$ $\mathrm{C} 50-\mathrm{C} 49$ is $177.99^{\circ}$. However, these three independent molecules have similar geometric parameters predicting three resonance structures.

\subsection{Thermogravimetric analysis}

Thermogravimetric analysis curves of compounds 1-5 were recorded to study their thermal stability as shown in figure 2. All the compounds were heated from 25 to $1000^{\circ} \mathrm{C}$ under nitrogen atmosphere. All silatranes show similar decomposition pattern and involved three steps. The first step of all silatranes involves the loss

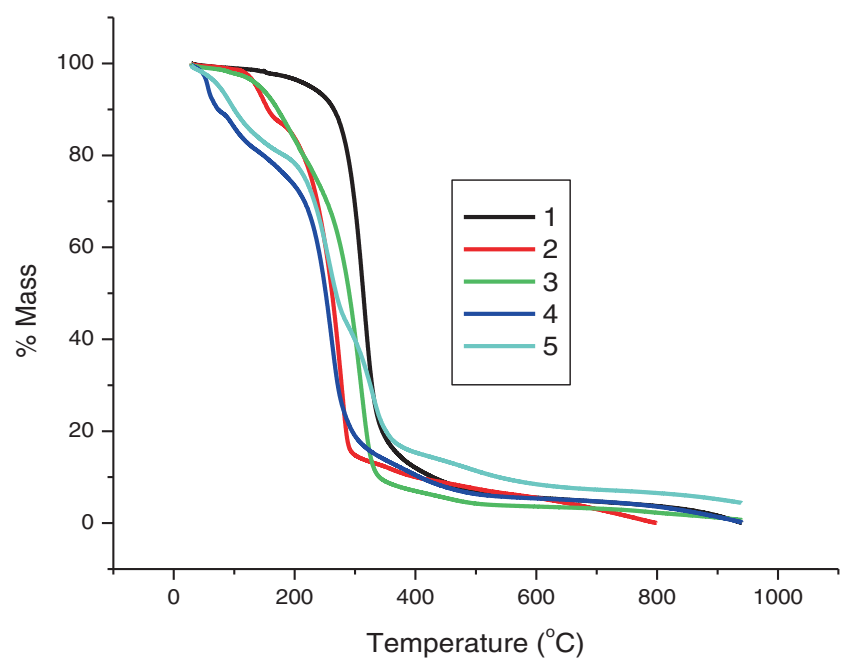

Figure 2. Thermo-gravimetrical Analysis for compounds 1-5. of ethanol for compounds $\mathbf{1} \mathbf{- 5}$. This step is confirmed from mass spectrum of all silatranes which shows a loss of one side arm of silatranyl moiety, which must be due to ethanol loss. This loss of ethanol is observed in the range of temperature 50 to $200^{\circ} \mathrm{C}$ for $\mathbf{1 - 5}$. The second step shows vertical curve due to complete loss of formed fragment in range of 200 to $430^{\circ} \mathrm{C}$. After annealing to $1000^{\circ} \mathrm{C}$, calculated residue weight of $\mathrm{SiO}_{2}$ was observed.

\section{Conclusions}

The Schiff bases of N-(2-Aminoethyl)-3-aminopropyltrimethoxysilane and their silatranes have been prepared successfully under suitable reaction conditions. Both silanes and their silatranes were found to be relatively stable. The stability to hydrolysis could overlay the path for silanes and hence useful in various reactions such as addition, nucleophilic substitution, exchange, complexation and photochemical reactions as silatranes are used in these reactions. The Schiff base modified silatranes could be significant for biological and catalytic properties due to incorporation of azomethine group at axial position of silatranes.

\section{Supplementary Information}

CCDC 979226 contains supplementary crystallographic data for compound $\mathbf{1}$. These data can be obtained free of charge from The Cambridge Crystallographic Data Centre via www.ccdc.cam.ac.uk. Supplementary data associated with this article can be found, in the online version, at www.ias.ac.in/chemsci. 


\section{Acknowledgments}

The authors are thankful to University Grants Commission, New Delhi for providing financial support.

\section{References}

1. Semenov V V, Cherepennikova N F, Khorshev S Y, Mushtina T G, Lopatin M A and Domrachev G A 2002 Russ. J. Coord. Chem. 28856

2. Dumitriu A, Cazacua M, Shovaa S, Turtaa C and Simionescu B C 2012 Polyhedron 33119

3. Wan S G, Yang X Y, Yu Y and Liu C 2005 Phosphorus, Sulfur Silicon Relat. Elem. 1802813

4. Puri J K, Singh R and Chahal V K 2011 Chem. Soc. Rev. 401791

5. Li Z, Tian D and Zhu C 2000 Phosphorus, Sulfur Silicon Relat. Elem. 16599

6. Xie Z, Chen L, Wang Y, Song X, Qi X, Guo P and Ye F 2014 Photochem. Lett. 8202

7. Singh R, Mutneja R, Kaur V K, Wagler J and Kroke E 2013 J. Organomet. Chem. 724186

8. Chuit C, Corriu R J P, Reye C and Young J C 1993 Chem. Rev. 931371
9. Verkade J G 1994 Coord. Chem. Rev. 137233

10. Cozzi P G 2004 Chem. Soc. Rev. 33410

11. Warncke G, Bohme U, Gunther B and Kronstein M 2012 Polyhedron $\mathbf{4 7} 46$

12. Gupta K C and Sutar A K 2008 Coord. Chem. Rev. 252 1420

13. Seiler O, Burschka C, Fenske T, Troegel D and Tacke R 2007 Inorg. Chem. 465419

14. M G Belyaeva V V and Abzaeva K A 2012 Chem. Heterocycl. Compd. 471330

15. Voronkov M G and Baryshok V P 2010 Her. Russ. Acad. Sci. 80985

16. Holmes R R 1990 Chem. Rev. 9017

17. Singh G, Saroa A, Garg M, Sharma R P, Gubanov A I and Smolentsev A I 2012 J. Organomet. Chem. 719 21

18. Singh G, Girdhar S, Khullar S and Mandal S K 2014 Inorg. Chim. Acta 413203

19. Singh G, Mangat S S, Singh J, Arora A and Sharma R K 2014 Tetrahedron Lett. 55903

20. APEX2 SADABS SAINT, Bruker AXS inc: Madison, WI, USA (2008)

21. Sheldrick G M 2008 Acta Cryst. A 64112

22. Imbernotte $M$, Palavit $G$, Legrand $P$, Huvenne J P and Fleury G 1983 Mol. Spectrosc. 10240 